\title{
PEDOWEATHERING AND MINERALOGICAL CHANGE IN CRYOSOLS IN AN ULTRA- CONTINENTAL CLIMATE (CENTRAL YAKUTIA, RUSSIA)
}

\author{
Sofia N. LESSOVAIA ${ }^{1)}$ *, Sergey V. GORYACHKIN ${ }^{2)}$, \\ Roman V. DESYATKIN ${ }^{3)}$ and Matrena V. OKONESHNIKOVA ${ }^{3)}$
}

\author{
1) St. Petersburg State University, Faculty of Geography and Geoecology, V.O., 10 line, 33, St. Petersburg, \\ 199178, Russia, +7-812-3233913 \\ 2) Institute of Geography, Russian Academy of Sciences, Staromonetny per.29, Moscow, 119017 Russia, \\ +7-495-9593786, \\ 3) Institute of Biological Problems of the Cryolithozone, Siberian Branch, Russian Academy of Sciences, pr. \\ Lenina 47, Yakutsk, 667891 Russia, +7-4112-335690 \\ *Corresponding author's e-mail: lessovaia@yahoo.com
}

(Received March 2013, accepted May 2013)

\begin{abstract}
This study investigates the clay mineralogy of permafrost-affected soils derived from predominantly calcareous loess-like material under the cold ultra-continental climatic conditions of Central Yakutia. These soils are named "Palevye (Pale)" following the Russian Classification, or Cryosols (WRB, 2006). Based on the data obtained, the loess-like substrate of Central Yakutia is enriched by chlorite in comparison with that of the loess-like parent material of European Russia. The clay mineralogy of the fine size fractions $(<1 \mu \mathrm{m}$ ) of all soil profiles is dominated by a smectitic mineral (most likely random mixed-layer illite-smectite and probably chlorite-smectite where smectite is $\geq 50 \%$ ), with subordinate chlorite and illite as well as the products of their transformation with smectite (vermiculite) layers $<50 \%$ in the upper horizons, and finally traces of kaolinite. Pedogenesis has brought about change in the more acidic upper horizons, including a marked reduction in the expandability of the smectitic phase, possibly accounted for by the introduction of non-exchangeable hydroxy-Al into the interlamellar space and / or partial dissolving of smectitic phase, together with a relative reduction in the contents of both illite and chlorite. Illite has been at least partially transformed to a mixed-layer illite-vermiculite (smectite), whereas chlorite has either been completely decomposed or has transformed to a mixed-layer expandable component. In one profile, the smectitic mineral appears to be absent from the upper horizon, suggesting that it may have been completely decomposed. An alternative explanation is that it has been eluted or translocated down the profile to accumulate in a Bt horizon. The distribution of clay minerals relates to the change of $\mathrm{pH}$ values in the profiles (acidic in the upper part, neutral - slightly alkaline in the middle, and alkaline in the basal horizons) possibly determined by seasonal migration of dissolved carbonates.
\end{abstract}

KEYWORDS: clay minerals, weathering in soil environment, cryosols, loess-like substrate

\section{INTRODUCTION}

Soils are closely related to the parent materials they are formed from and thus to Earth geodynamic processes. A second most influential factor of soil formation is that of climate and of the climate-induced biota. Currently, the global soil science community is in a process of flux because of new challenges and the responses required. Thus, the overall needs of mankind urgently require knowledge of soil behaviour induced by global change and have resulted in the development of large international projects involving new soil surveys and related in-depth studies. For example, projects such as the "Digital Soil Map of the World" are to be based on soil properties (Sanchez et al., 2009) and the "Universal Soil Classification" embraces information on soils gathered at a new level of investigation (Golden et al., 2010). Both of these projects need information on soils of large areas that are not well known from previous periods of soil survey. One such territory is Central Yakutia located in the Central Yakutia plain at an altitude of less than
$400 \mathrm{~m}$. Pedogenesis in this permafrost-affected zone has taken place in the cold ultra-continental climatic conditions that are sufficiently different from those of more humid climates in which permafrost-affected soils are wide spread (Kimble, 2004). That is why the study of permafrost-affected soils in such specific conditions should enrich essentially the general understanding of pedogenic processes (e.g. pedoweathering) in the area of cold soils.

The properties, genesis, and classification of soils of Central Yakutia have been documented generally in Russian (Gerasimov, 1963; Elovskaya, 1987; Ivanova, 1971; Sokolov, 1991; Desyatkin et al., 2009). The soils named "Palevye (Pale)" following the Russian Classification are calcareous and mostly formed on the loess-like substrate. An attempt to determine the position of these soils in a "Classification and diagnostic system of Russian soils" (2004) based on morphology, analytical characteristic, and clay mineralogy has been made recently (Desyatkin et al., 2011). Nevertheless many aspects of 
soil genesis, and especially mineralogy, are still poorly known for the very specific and vast region of Siberia. The goal of this paper is to investigate the nature and distribution of the clay minerals in several permafrost-affected soils of Central Yakutia, to elucidate the specific soil processes involved and to consider any differences there may be with soils from similar landscapes.

\section{OBJECTS AND STUDY LOCATION}

The studied soil profiles are situated in Central Yakutia with GPS coordinates at $61-62^{\circ} \mathrm{N}$ and 129 $133^{\circ} \mathrm{E}$ (Fig. 1). Geologically, this territory consists of Pleistocene river terraces overlain by predominately calcareous loess-like material. The climate is sharply continental. Mean annual air temperatur e is -10 to $-11{ }^{\circ} \mathrm{C}$, but with great seasonal contrast: the mean monthly temperature in July is $+18-+19{ }^{\circ} \mathrm{C}$ and in January $-35--45{ }^{\circ} \mathrm{C}$. Extreme temperatures are $+38{ }^{\circ} \mathrm{C}$ and $-64{ }^{\circ} \mathrm{C}$. The mean annual precipitation is 210 - $220 \mathrm{~mm}$, which is less than potential evapotranspiration $(250-300 \mathrm{~mm})$. However, the perennial variation of precipitation is high and wet years may have $>300 \mathrm{~mm}$. Central Yakutia is a territory with continuous permafrost at depths of 150 $250 \mathrm{~m}$. The thawing depth is from 0.5 to $2.5 \mathrm{~m}$ depending on the substrate and the landscape. The permafrost is a very important source of moisture making possible forest growth (Sugimoto et al., 2002), here dominated by larch (Larix cajanderi), pine (Pinus sylvestris) and birch (Betula platyphilla) with a small admixture of spruce (Picea obovata).

Several dozens of soil profiles were excavated and described and four of the most representative were sampled for the study of clay mineralogy. The studied "Palevye (Pale)" soils, classified according to World Reference Base for Soil Resources (2006), are represented by Pit 10-03 of Cambic Calcic Cryosol (Siltic, Magnesic): AO (0-6 cm) - Bw (6-22 cm) $\mathrm{Bk}(\mathrm{f}) \quad(22-65 \mathrm{~cm})$; Pit $18-03$ of Cambic Calcic Cryosol (Siltic, Luvic): O $(0-3 \mathrm{~cm})-\mathrm{A}(3-7 \mathrm{~cm})-\mathrm{AE}$ $(7-15 \mathrm{~cm})-\mathrm{Bt}(15-41 \mathrm{~cm})-\mathrm{Bk}(\mathrm{f})(41-91 \mathrm{~cm})$; Pit 107 of Cambic Turbic Cryosol (Reductaquic): AO (0$10 \mathrm{~cm})-\mathrm{Bw}(10-20 \mathrm{~cm})-\mathrm{Bw}_{@}(20-57 \mathrm{~cm})-\mathrm{Bk}_{@}$ $(57-75 \mathrm{~cm})-\mathrm{Bkg}_{@} \mathrm{f}(75-100 \mathrm{~cm})$; and Pit 2-07 of Cambic Calcic Turbic Cryosol: O (0-4 cm) - AO (4$9 \mathrm{~cm})-\mathrm{Bwh}(9-19 \mathrm{~cm})-\mathrm{Bw}_{@}(19-44 \mathrm{~cm})-\mathrm{Bk}_{@}(44-$ $114 \mathrm{~cm})-\mathrm{Bkf}_{@}(114-124 \mathrm{~cm})$.

\section{METHODS}

$\mathrm{pH}$-values were measured potentiometrically in $\mathrm{H}_{2} \mathrm{O}$ with a soil:water ratio of $1: 2.5$. Extraction and content of soil organic matter (C) was determined by the wet combustion method of Tyurin. In the upper horizons: AO enriched by decomposed soil organic matter and $\mathrm{O}$ loss on ignition was determined. The forms of soluble iron in the $<1 \mathrm{~mm}$ fractions were obtained by using the dithionite-citrate-bicarbonate method (Mehra and Jackson, 1958) and in the non-

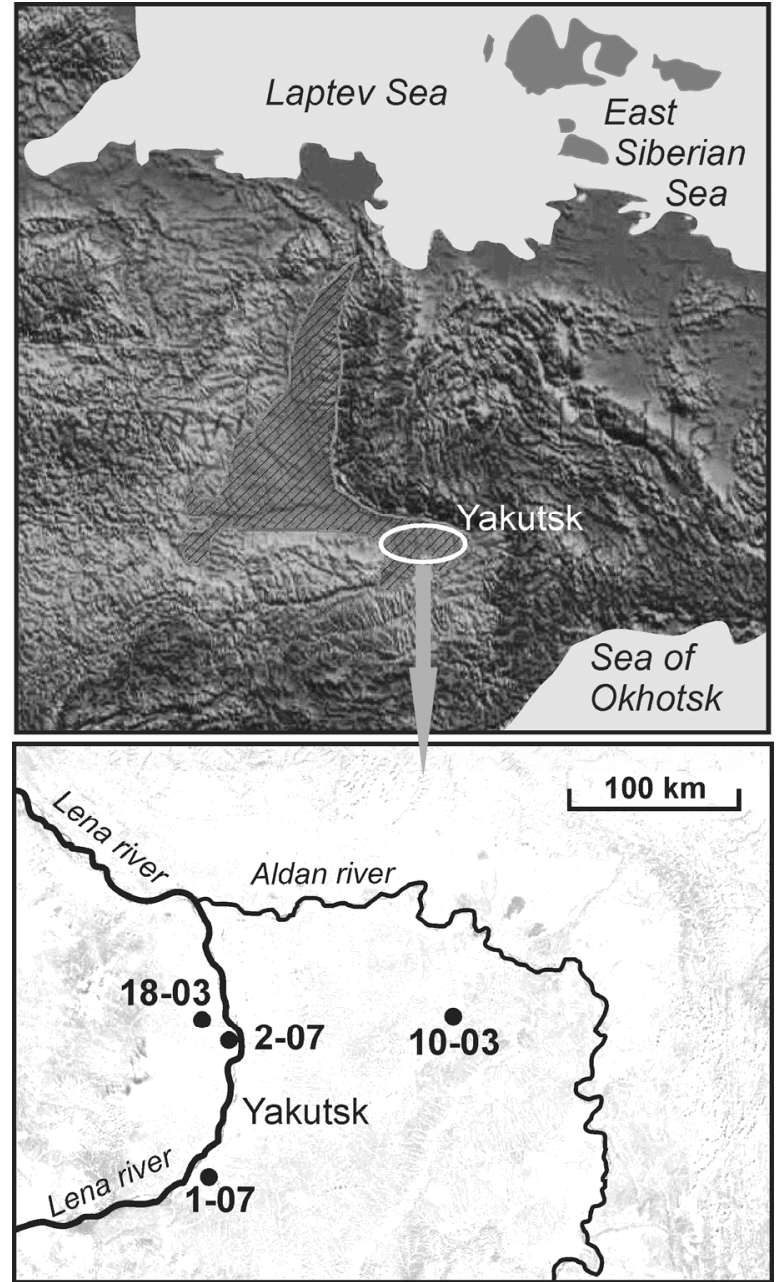

Fig. 1 Location of study site and key plots in Siberia.

calcareous horizons by extraction with oxalate (Jackson et al., 1986). The carbonate presence was identified in the field by adding some drops of $10 \%$ $\mathrm{HCl}$ to the samples. The $<1 \mathrm{~mm}$ fraction of the soils were obtained by gentle grinding and disaggregation with subsequent dry sieving. Carbonates in calcareous samples were dissolved by $9 \%$ acetic acid.

The $<1 \mu \mathrm{m}$ fractions from soil horizons were separated by sedimentation and decantation, followed by dispersion by addition of a few drops of ammonia as a peptizing agent. The mineralogical composition of the $<1 \mu \mathrm{m}$ soil fractions was investigated using a DRON-2 X-ray diffractometer with $\mathrm{CoK} \alpha$ radiation and a monochromator in the diffracted beam. Pretreatment of the $<1 \mu \mathrm{m}$ fractions included (i) saturation with $\mathrm{Mg}$; (ii) ethylene glycol solvation; and (iii) heating at $550^{\circ} \mathrm{C}$ for $3 \mathrm{~h}$. The samples studied by $\mathrm{X}$-ray diffraction were also investigated by FTIR spectroscopy. FTIR spectra in the $400-4000 \mathrm{~cm}^{-1}$ range were obtained using a Tensor 27 spectrometer (Bruker) with a resolution of $4 \mathrm{~cm}^{-1}$ in ambient air and at room temperature. Spectra were recorded in the transmission mode using $\mathrm{KBr}$ pellets. The $\mathrm{KBr}$ and clay samples were heated in a furnace overnight at 
Table 1 Some properties of the studied soils.

\begin{tabular}{|c|c|c|c|c|c|c|c|}
\hline \multirow{3}{*}{ Horizon, depth $(\mathrm{cm})$} & \multirow{3}{*}{$\begin{array}{c}\mathrm{pH} \\
\mathrm{H}_{2} \mathrm{O}\end{array}$} & \multirow{3}{*}{$\begin{array}{c}<1 \mu \mathrm{m} \\
(\%)\end{array}$} & \multirow{3}{*}{$\begin{array}{c}\text { LI } \\
(\%)\end{array}$} & \multirow{3}{*}{$\begin{array}{c}\mathrm{C} \\
(\%)\end{array}$} & \multicolumn{3}{|c|}{$\mathrm{Fe}_{2} \mathrm{O}_{3}$} \\
\hline & & & & & $\mathrm{d}$ & o & $\mathrm{o} / \mathrm{d}$ \\
\hline & & & & & \multicolumn{2}{|c|}{$(\%)$} & \\
\hline \multicolumn{8}{|c|}{ Pit 10-03, Cambic Calcic Cryosol (Siltic, Magnesic) } \\
\hline $\mathrm{AO}(0-6)$ & 4.0 & - & 93.2 & - & - & - & - \\
\hline $\mathrm{Bw}(6-22)$ & 7.0 & 22.9 & - & 2.1 & 0.58 & 0.32 & 0.55 \\
\hline $\operatorname{Bk}(\mathrm{f})(22-65)$ & 8.0 & 22.9 & - & 1.3 & 0.31 & - & - \\
\hline \multicolumn{8}{|c|}{ Pit 18-03, Cambic Calcic Cryosol (Siltic, Luvic) } \\
\hline A (3-7) & 5.6 & 8.2 & _- & 3.4 & 0.44 & 0.33 & 0.75 \\
\hline $\mathrm{AE}(7-15)$ & 7.5 & 11.9 & - & 0.9 & 0.53 & 0.26 & 0.49 \\
\hline $\mathrm{Bt}(15-41)$ & 7.6 & 26.2 & - & 0.5 & 0.56 & 0.26 & 0.46 \\
\hline $\mathrm{Bk}(\mathrm{f})(41-91)$ & 8.5 & 18.5 & - & 0.4 & 0.33 & - & - \\
\hline \multicolumn{8}{|c|}{ Pit1-07, Cambic Turbic Cryosol (Reductaquic) } \\
\hline $\mathrm{AO}(0-10)$ & 4.8 & 23.4 & - & 4.3 & 1.51 & 0.71 & 0.47 \\
\hline Bw $(10-20)$ & 6,0 & 26.6 & - & 1.3 & 1.74 & 0.51 & 0.29 \\
\hline $\mathrm{Bw}_{@}(20-57)$ & 7.3 & 32.1 & - & 0.5 & 1.55 & 0.21 & 0.13 \\
\hline $\mathrm{Bk}_{@}(57-75)$ & 8.3 & 22.9 & - & 0.5 & 1.40 & - & - \\
\hline $\mathrm{Bkg}_{@} \mathrm{f}(75-100)$ & 8.1 & 32.3 & - & 0.4 & 1.63 & - & - \\
\hline \multicolumn{8}{|c|}{ Pit 2-07, Cambic Calcic Turbic Cryosol } \\
\hline $\mathrm{O}(0-4)$ & 5.0 & - & 49.4 & - & - & - & - \\
\hline $\mathrm{AO}(4-9)$ & 4.4 & 11.1 & 27.5 & - & 0.35 & 0.25 & 0.71 \\
\hline Bwh (9-19) & 6.3 & 7.8 & - & 1.4 & 0.34 & 0.28 & 0.82 \\
\hline $\mathrm{Bw}_{@}(19-44)$ & 7.7 & 11.1 & - & 0.2 & 0.28 & 0.22 & 0.78 \\
\hline $\mathrm{Bk}_{@}(44-114)$ & 8.0 & 15.6 & - & 0.3 & 0.27 & - & - \\
\hline $\mathrm{Bkf}_{@}(114-124)$ & 8.2 & 12.3 & - & 0.2 & 0.29 & - & - \\
\hline
\end{tabular}

Abbreviations and notes: $\mathrm{d}$ - dithionite and o - oxalate extractable $\mathrm{Fe}_{2} \mathrm{O}_{3}$, ' - ' - no data available; $<1 \mu \mathrm{m}$ - content of particle size $<1 \mu \mathrm{m}$ in the $<1 \mathrm{~mm}$ fraction; LI - loss on ignition; $\mathrm{C}$ - soil organic matter, \%

$105{ }^{\circ} \mathrm{C}$ to minimize adsorbed water, and $1 \mathrm{mg}$ of sample and $300 \mathrm{mg}$ of $\mathrm{KBr}$ thoroughly mixed, pressed to a transparent pellet and their IR spectra recorded.

\section{RESULTS}

\section{PHYSICOCHEMICAL PROPERTIES AND TEXTURE.}

The studied soils are characterized by high soil organic matter contents, represented by raw humus, in the topmost $\mathrm{O}, \mathrm{AO}$, and $\mathrm{A}$ horizons and by relatively low soil organic matter contents in the mineral horizons. The $\mathrm{pH}$ values in the profiles change from acidic in the upper horizons $(4.0-5.6)$, to weakly acidic to slightly alkaline in the middle horizons (6.0 7.7) and to alkaline in the basal horizon (8.0 - 8.5). Based on the relative proportions of dithionite- and oxalate-soluble iron, the studied soils could be split into two groups: (i) Pits 10-03, 18-03, and 2-07 with extremely low content $(<0.6 \%)$ of dithionite-soluble iron and (ii) Pit 1-07 with much higher content (1.40 $1.74 \%)$. This higher amount is reflected by the more reddish color of both the substrate and the soil and could be explained by an admixture of pre-Quaternary material. In the soils of the first group most of the dithionite-extractable iron could be accounted for by amorphous + poorly crystallized (oxalate extractable) iron, especially in Pit 2-07 which is characterized by a relatively low clay content. In Pit 1-7, there is a slightly pronounced accumulation of oxalate extractable iron in the $\mathrm{AO}$ and $\mathrm{Bw}$ horizons.

The profiles have developed on a loess-like substrate apart from the Cambic Calcic Turbic Cryosol (Pit 2-07) which is characterized by a more sandy texture. The distribution of the clay size fraction is somewhat irregular, particularly in Pits 1-07 and 2- 
07, and in the lower horizons of Pit 18-03. These irregularities are most likely due to textural variation in the parent material. The clay content in Pit 10-03 shows no variation with depth. In the Pit $18-03$ a well pronounced texture differentiation is detected both by morphological features and clay distribution. It is likely related to exchanging sodium $\left(\mathrm{Na}^{+}\right)$, as this soil has $10 \%$ of exchanging sodium (Desyatkin et al., 2011) and is named "Solodic Pale soil" according to the local classification (Desyatkin et al., 2009).

\section{MINERALOGY}

The minerals identified in the clay fractions of all profiles are as follows: (i) chlorite, (ii) illite or interlayer-cation-deficient mica (Rieder et al., 1998), (iii) smectite and / or mixed-layer smectitic minerals with a high $\geq 50 \%$ amount of expandable layers, (iv) mixed-layer minerals with a small amount of expandable layers, (v) kaolinite, and (vi) quartz.

Chlorite identification is based on the 001 and 003 basal reflections at $14.0-14.2 \AA$ and $4.75 \AA$ respectively that are stable after ethylene glycol solvation and showing a slight contraction of the 001 peak to $13.8 \AA$ after $550^{\circ} \mathrm{C}$ treatment.

Illite is recognized by peaks at the 001 and 002 basal reflections at $10.0 \AA$ and $5.0 \AA$ respectively that remain stable after ethylene glycol and heat treatments.

Highly smectitic clays are identified by the response to ethylene glycol solvation whereby a peak at $\sim 14 \AA$ in the Mg-saturated air-dry state shifts to a fundamental 001 spacing of $\geq 17 \AA$. As the 002 reflection at $8.49 \AA$, which is characteristic of a pure smectite (montmorillonite or beidellite) mineral, is not detected it is probable that the expandable phase represents a random mixed-layer structure with a nonexpandable phase such as illite. The high background towards the low angle side of the $17 \AA$ peak is typical of a random mixed-layer illite-smectite structure where the smectite layers exceed 50\% (Reynolds, 1980).

Mixed-layer clays with minor proportions of smectite or vermiculite layers are recognized by the asymmetries of the $10.0 \AA$ illite and $14 \AA$ chlorite peaks on XRD patterns of $\mathrm{Mg}$ saturated and heated samples respectively and suggest the presence of random mixed layer structures (Figs. 2, 3).

Kaolinite is recognized by its 001 reflection at $7.14 \AA$ which disappears after heating at $550{ }^{\circ} \mathrm{C}$. The identification is confirmed by FTIR spectroscopy data that enables kaolinite to be identified in the presence of chlorite. IR spectroscopy is a sensitive method for the detection of kaolinite (Delvaux et al., 1989). The absorption bands near $3700 \mathrm{~cm}^{-1}$ (the vibration of inner surface $\mathrm{OH}$ groups), $3627 \mathrm{~cm}^{-1}$ (the stretching vibration of inner $\mathrm{OH}$ groups), $914 \mathrm{~cm}^{-1}$ (bending vibration of inner $\mathrm{OH}$ groups), $540 \mathrm{~cm}^{-1}$ (Si-O-Al bending vibrations), and $470 \mathrm{~cm}^{-1}$ (Si-O-Si bending vibrations) all indicate the presence of kaolinite (Madejová and Komadel, 2001; Pentrak et al., 2009).
Quartz is identified by its characteristic XRD peaks at 3.34 and $4.26 \AA$ and by its most typical IR absorption band doublet at $800-780 \mathrm{~cm}^{-1}$ (Hlavay et al., 1978; Madejová and Komadel, 2005) (Fig. 2).

\section{DISTRIBUTION OF CLAY MINERALS}

Using the above criteria, the distribution of the various clay minerals within the profiles of the Cryosols studied may now be summarized as follows:

Cambic Calcic Cryosol (Siltic, Magnesic) (Pit 10-03). There is little difference in the clay mineralogy of the $\mathrm{Bw}$ and $\mathrm{Bk}(\mathrm{f})$ horizons, both being characterized by mixed-layer smectite (most likely probably illite-smectite and probably chloritesmectite), chlorite, illite, kaolinite and quartz.

Cambic Calcic Cryosol (Siltic, Luvic) (Pit 1803). The essential clay mineralogy of this soil, particularly in the two B horizons, is rather similar to that described above, but clear differences are found in both the A and AE horizons. Thus the intensity of the diffraction peak (001) for the smectitic mineral is much diminished in the $\mathrm{AE}$ horizon while in the A horizon it practically disappears. The same is true of the $14.2 \AA$ chlorite peak which in the A horizon appears to be replaced by a weak $12 \AA$ peak in the Mg-saturated state. The intensities of both the illite and kaolinite basal reflections are also severely diminished in the A horizon.

Cambic Turbic Cryosol (Reductaquic) (Pit 1-07). The clay mineralogy of the four B horizon samples, ranging in depth from 10 to $100 \mathrm{~cm}$, are essentially similar to each other and to that of the B horizons of the soils just described. A mixed-layer smectitic clay (probably interstratified illite-smectite) is the dominant mineral with subsidiary amounts of chlorite, illite, kaolinite, and trace amounts of quartz. There is a clear change, however, in the upper AO horizon with a marked decrease in the content of the expandable smectitic clay, as well as a reduction in the amount of chlorite as indicated by the barely perceptible $13.8 \AA$ peak after heating at $550{ }^{\circ} \mathrm{C}$ accompanied by weak diffraction maxima in 10 to $14 \AA$ region. It is noted too that the $10 \AA$ indicative of illite becomes progressively weaker in the $\mathrm{Bw}$ horizons and is barely detectable in the AO horizon.

Cambic Calcic Turbic Cryosol (Pit 2-7). The same trends are found in this soil although it is notable that the expandable smectitic phase persists throughout the profile and into the AO horizon where it remains the dominant clay mineral. Both illite and chlorite are severely reduced in the AO horizon compared with the underlying Bwh horizon.

\section{DISCUSSION}

Based on the above data the loess-like substrate of Central Yakutia is enriched in chlorite in comparison with the loess-like parent material of European Russia, where a "hydromica-smectite" composition has been reported (Gradusov, 2000). Despite their close mineralogical similarities, the 


\section{Pit 10-03}

I
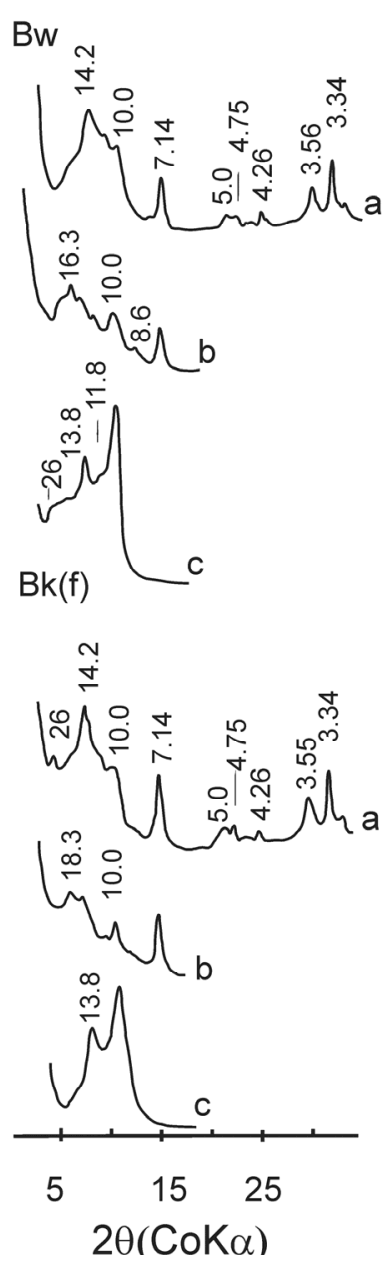

II

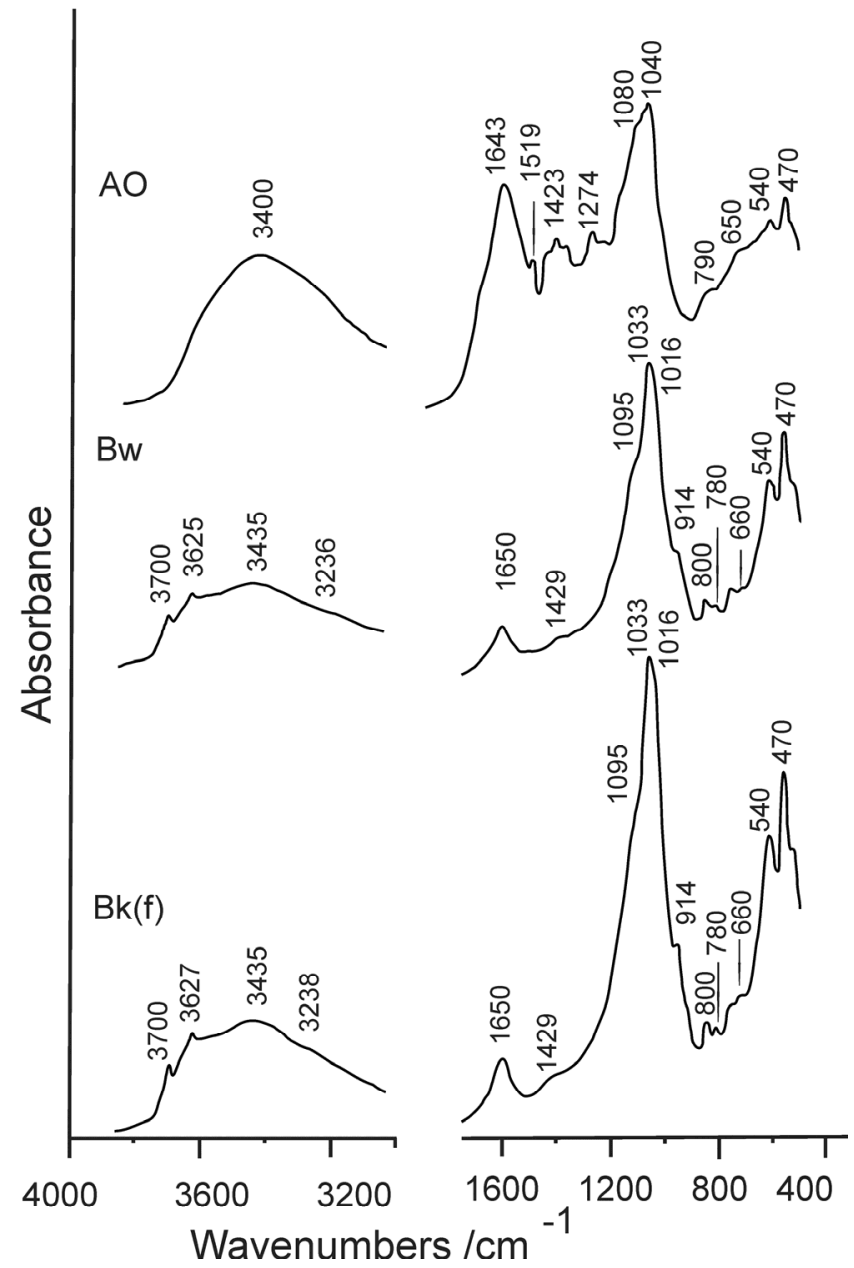

Fig. 2 XRD patterns (I) and FTIR spectra (II) of the $<1 \mu \mathrm{m}$ fraction of Pit 10-03, Cambic Calcic Cryosol (Siltic, Magnesic); a - Mg-saturated, b - ethylene glycol solvated, c $550{ }^{\circ} \mathrm{C}$ treatment, $d$-values are given in Angstrom.

studied soils illustrate some possible scenarios relating to the processes involved in the distribution of clay minerals in soil profiles affected by permafrost. The possibility of pedogenic weathering of clay minerals in Cryosols has been recently illustrated by a study of such soils in much colder conditions in ice-free areas of Admiralty Bay, King George Island (Simas et al., 2006).

Little mineralogical change can be observed in the B horizons of the Cambic Calcic Cryosol (Siltic, Magnesic) (Pit 10-03) over a depth of 6 to $65 \mathrm{~cm}$. This may be explained by the neutral - alkaline $\mathrm{pH}$ values of these horizons and strongly suggests that all the clay minerals identified have been simply inherited from the loess-like parent material. It is of interest, however, that a pronounced vermiculitization of illite has been observed even in non-acidic arctic tundra Gelisols of Northern Alaska (Borden et al., 2010), although these soils formed in more moist conditions compared with the Cryosols of Yakutia. An additional factor that may be relevant to the weak differentiation of the clay minerals in some of the studied profiles is that the high content of the fine size fraction, enriched in phyllosilicates, tends to make any change unnoticeable.

In the Cambic Turbic Cryosol (Reductaquic) (Pit 1-07) there is a decrease in the smectitic phase in the more acidic upper horizons, as well as a decrease in the chlorite content. The transformation of illite and chlorite to randomly interstratified illite-smectite and chlorite-smectite respectively in circum-neutral to weakly acidic conditions has been documented for permafrost-affected soils Kriozems (Cryosols) formed in the cold, continental, climate of the Kolyma Lowland, North-East Siberia, as has the extremely weak intensity of chemical weathering of the Yedoma deposits (Alekseev et al., 2003). 


\section{Pit 18-03}

A
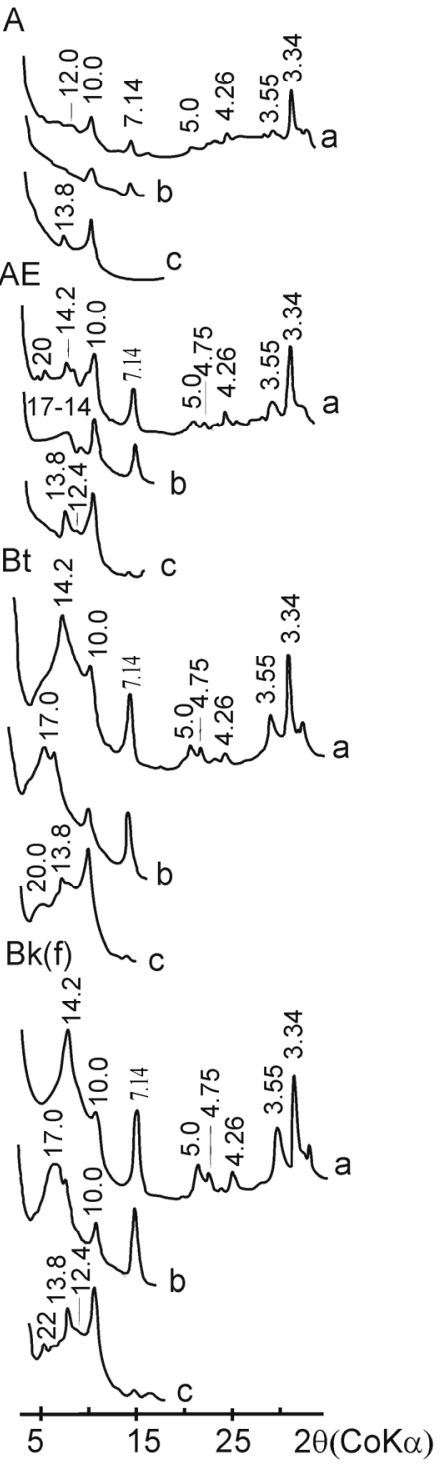

Pit 1-07
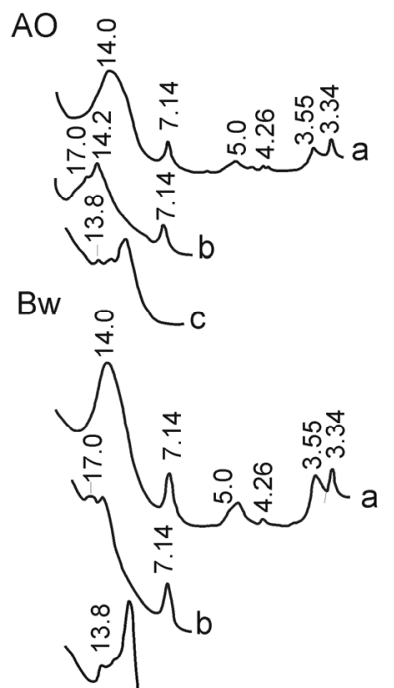

Bw@
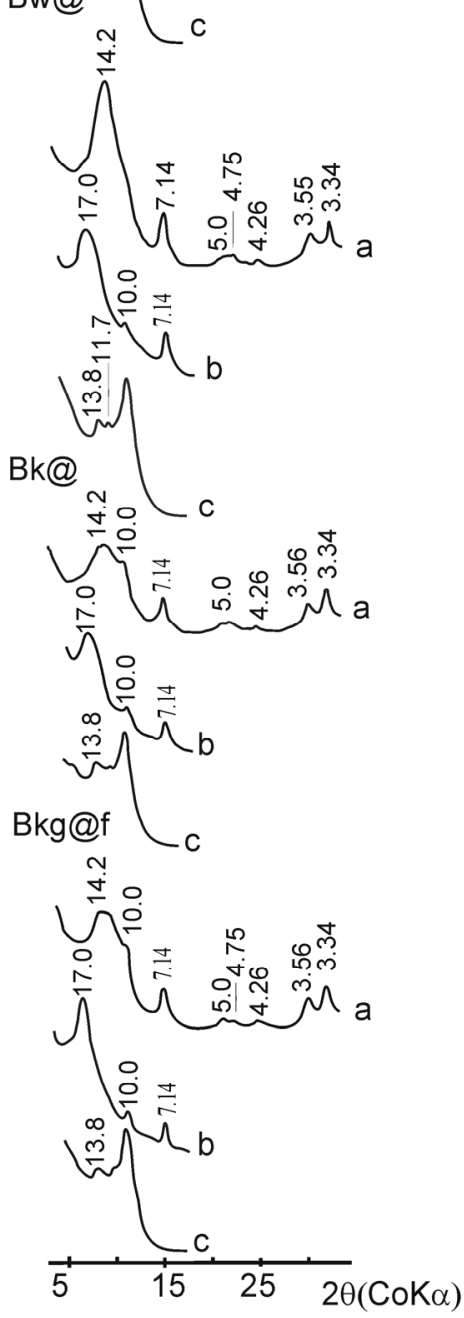

Pit 2-07

$\mathrm{AO}$
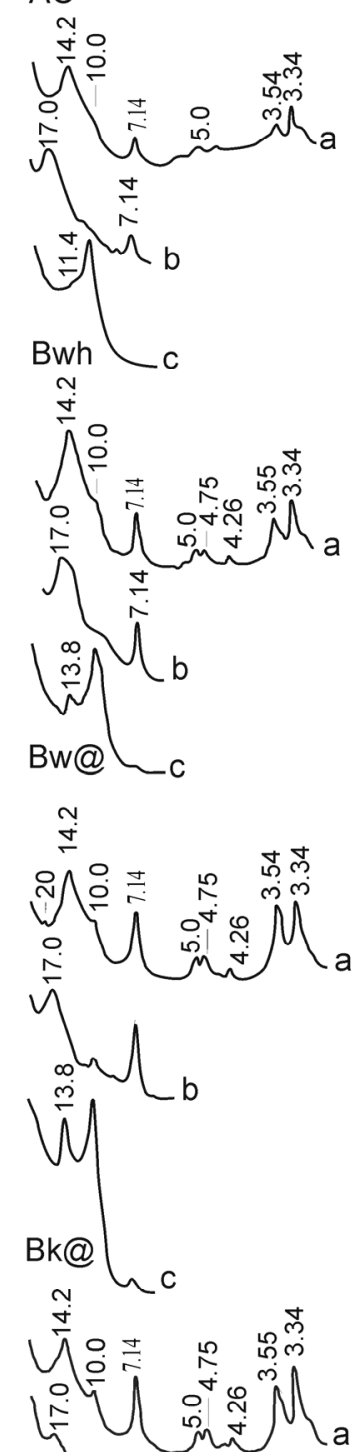

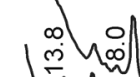

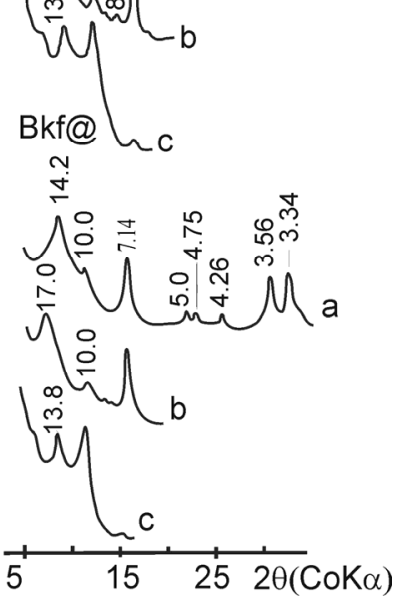

Fig. 3 XRD patterns of the $<1 \mu \mathrm{m}$ fraction of the soils: Pit 18-03 of Cambic Calcic Cryosol (Siltic, Luvic), Pit 1-07 of Cambic Turbic Cryosol (Reductaquic), and Pit 2-07 Cambic Calcic Turbic Cryosol. 
In the upper part of the Cambic Calcic Turbic Cryosol (Pit 2-07) both illite and chlorite appear to decrease significantly. These upper horizons are acidic and may well have been affected by the vegetation community, especially mosses and lichens which are abundant on the surface of this soil. The overall proportion of the smectitic phase may possibly reduce in the upper horizons, as suggested by a decrease in intensity of the peak at $\sim 14 \AA$ in the $\mathrm{Mg}$-saturated sample although there is little corresponding decrease in the intensity of the peak at $17 \AA$ after glycol treatment. Significant losses of chlorite and mica, as well as the appearance of smectitic phases, have been reported in a soil formed in cold climatic conditions (Egli et al., 2003; Mavris et al., 2010). Thus, the presence of smectitic phase in the acidic upper horizons bearing in mind the decrease of shares of illite and chlorite can be explained by those minerals transformations.

More pronounced chlorite weathering is shown in the mildly acidic upper horizons of Cambic Calcic Cryosol (Siltic, Luvic) (Pit 18-03). The higher $\mathrm{pH}$ value of the upper horizon is in a good agreement with the influence of the vegetation community which is represented by grasses and herbs without an admixture of moss. In this profile, an eluvial morphology is evident, with clay material being translocated down the profile to yield a distinct $\mathrm{Bt}$ horizon. As it was mentioned above, these features could relate to the presence of $\mathrm{Na}^{+}$on the cation exchange complex, as documented by Desyatkin et al. (2011). On the other hand, the weathering in the upper horizons of the profile suggests the influence of more acidic conditions than indicated by current $\mathrm{pH}$ values. Solution chemistry may however be determined by a cyclical process relating to inherited carbonate in the parent material, with dissolved carbonate migrating downward in wet seasons and upward toward the freezing front in autumn.

It is evident that the clay mineralogy of the Cryosols investigated has been significantly affected to various degrees during the process of soil formation, particularly in the upper, more acidic horizons. These changes affect the dominant smectitic phase, illite and chlorite, all of which have been inherited from the loess-like parent material. The smectitic phase, whose X-ray characteristics are entirely consistent with random mixed-layer illitesmectite and probably chlorite-smectite where the proportion of smectite layers is $\geq 50 \%$, is relatively unaffected in the Cambic Calcic Cryosol of Pit 10-03.

In the upper horizons of the Cryosols of Pits 107 and 2-07 there is a distinct reduction in the expandability of the smectitic phase, whereas in the Cambic Calcic Cryosol of Pit 18-03 the relative proportion of the smectitic phase is markedly reduced in the AE horizon and it seemingly disappears in the A horizon. Loss of expandability of smectitic clays is often observed in the acidic upper horizons of soils developed under a cool humid climate, such as
Podzols and Brown forest soils, in Europe and North America (Wilson et al., 1984; Wilson, 1999). Generally, this feature is attributed to the introduction of non-exchangeable hydroxy- Al into the interlayer space so inhibiting both the swelling capacity and the ability to contract to $10 \AA$ after heat treatment of the smectitic clay. Interlayering proceeds most effectively at $\mathrm{pH}$ values between $\sim 4.4$ to 5.6 , which is within the range of the $\mathrm{pH}$ values of the uppermost horizons of the Cryosols from Pits 1-07 and 2-07, but where $\mathrm{pH}$ falls below 4.3 then the hydroxyl-Al converts to the $\mathrm{Al}^{3+}$ ion. Another explanation of decrease of expandable phase portion is its partial dissolving in the upper acidic horizons. In the Cryosol from Pit 1803 , however, it is apparent that the smectitic phase is absent from the A horizon and is much decreased in quantity in the AE horizon. Although these features might be explained by the decomposition of the smectitic phase, another possibility is that the clay has been eluviated down the profile to accumulate in the underlying Bt horizon. This might be a more likely explanation bearing in mind the mildly acidic character of the topmost horizon ( $\mathrm{pH} 5.6)$ and the alkaline reactions of those underlying it ( $\mathrm{pH}$ 7.5-8.5).

With regard to the changes noted in the illite and chlorite components of the $<1 \mu \mathrm{m}$ fractions, similar changes have been noted too in Podzolic and Brown forest soils in Europe and North America. Illite normally loses interlayer potassium and converts to a mixed layer dioctahedral illite-vermiculite in the upper acidic horizons of such soils or even to illitesmectite as it was shown for soils of Yedoma deposits (Alekseev et al., 2003) and it seems that this is a likely explanation for the loss of illite in the upper horizons of the Cryosols. The situation with regard to chlorite is more problematical as complete decomposition of the clay mineral occurs in some soils (Bain, 1977), which is not surprising bearing in mind its susceptibility to acid dissolution in the laboratory, whereas in other soils it has been proposed that the mineral forms interlayered and mixed-layer clays (De Coninck et al, 1983; Righi et al, 1993). Although there is not enough evidence to decide upon these two possibilities, it is of interest that there seems to be no relationship between intensity of chemical weathering and increase of oxalate extractable iron. The nonsystematic distribution of this form of iron in the soils of Yakutia has also been noted by Ivanova (1971).

In conclusion, the clay mineralogy and the specific clay mineral changes noted in the permafrostaffected soils studied here are determined by the interaction of the various soil forming factors first identified by Dokuchaev in the $19^{\text {th }}$ century. The preponderant factor in this case is parent material as it seems almost certain all the clay minerals identified have been inherited from the underlying loess-like deposit. However, the continental climatic conditions and the vegetation communities have combined to create acid conditions in the upper parts of the soil profiles and this has brought about change in the 
nature and distribution of the clay minerals within the soil profiles. A seasonal migration of dissolved carbonates from and to the parent material at the base of the profiles during spring and autumn may also have influenced the $\mathrm{pH}$ distribution within the Cryosols.

\section{CONCLUSION}

The clay mineralogy of the fine size fractions $(<1 \mu \mathrm{m})$ of a set of Cryosols in north east Siberia is characterized by the dominant occurrence of a highly smectitic phase (most likely mixed-layer illitesmectite and probably chlorite-smectite), subordinate illite and chlorite, and with traces of kaolinite. All these minerals have been inherited from the loess-like parent material. Pedogenesis has brought about change in the more acidic upper horizons, including a marked reduction in the expandability of the smectitic phase, possibly accounted for by the introduction of non-exchangeable hydroxy-Al into the interlamellar space or partial dissolving of smectitic phase, and a reduction in relative contents of both illite and chlorite. Illite has been at least partially transformed to a mixed-layer illite-vermiculite (smectite), whereas chlorite has either been completely decomposed or has transformed to a mixed-layer expandable component. In one profile, the smectitic mineral appears to be absent from the upper horizon, suggesting that it may have been completely decomposed. An alternative explanation is that it has been eluted or translocated down the profile to accumulate in a Bt horizon.

\section{ACKNOWLEDGEMENTS}

The authors are grateful to the reviewers for helpful suggestions and very useful remarks.

\section{REFERENCES}

Alekseev, A., Alekseeva, T., Ostroumov, V., Siegert, C. and Gradusov B.: 2003, Mineral transformation in permafrost-affected soils, North Kolyma Lowland, Russia. Soil Science Society of America Journal., 67, 596-605.

Bain, D.C.: 1977, The weathering of some chlorite minerals in Scottish soils. Journal of Soil Science., 28, 144164.

Borden, P.W., Ping, C.-Lu., McCarthy, P.J. and Naidu, S.: 2010, Clay mineralogy in Arctic Tundra Gelisols, Northern Alaska, Soil Science Society of America Journal., 74(2), 580-592. DOI: $10.2136 /$ sssaj2009.0187

Classification and Diagnostic System of Russian Soils: 2004, Oikumena, Smolensk, 342 pp., (in Russian).

De Coninck, F., van Ranst, E. and Jensen, W.: 1983. Trioctahedral and dioctahedral chlorite in soils: examples of a Dystrochrept (Corsica), a Cryorthod (Norway) and a Hapludalf (France). In: Nahon, D. and Noack, Y. (Eds.): Pétrologie des altérations et des sols, Sciences géologiques. Mémoire, Strasbourg., 73, 75-84.

Delvaux, B., Mestdagh, M.M., Vielvoye, L. and Herbillon, A.J.: 1989, XRD, IR and ESR study of experimental alteration of Al-nontronite into mixed-layer kaolinite/smectite, Clay Minerals., 24, 617-630.

DOI: 10.1180/claymin.1989.024.4.05

Desyatkin, R.V., Okoneshnikova, M.V. and Desyatkin, A.R.: 2009, Soils of Yakutia, Bichik, Yakutsk, 64 pp. (in Russian).

Desyatkin, R.V., Lesovaya, S.N., Okoneshnikova, M.V. and Zaitseva T.S.: 2011, Palevye (Pale) soils of Central Yakutia: genetic specificity, properties, and classification, Eurasian Soil Science., 44, No. 12, 1304-1314. DOI: 10.1134/S1064229311120027

Egli, M., Mirabella, A. and Fitze, P.: 2003, Formation rates of smectites derived from two Holocene chronosequences in the Swiss Alps, Geoderma., 117, 81-98. DOI: 10.1016/S0016-7061(03)00136-8

Elovskaya, L.G.: 1987, Classification and Diagnostics of Permafrost Affected Soils of Yakutia, YaF SO Akademia Nauk SSSR, Yakutsk, 172 pp, (in Russian).

Gerasimov, I. P.: 1963, Specificity of Genetic Soil Types in Siberia. In: Siberian geographic digest. Akad. Nauk SSSR, Moscow, 10-25, (in Russian).

Gradusov, B.P.: 2000, The world map of soil-forming and underlying rocks, its genetic and geographic analysis, and the regularities of soil formation, Eurasian soil science., No. 2, 156-169.

Golden, M., Micheli, E., Ditzler, C., Eswaran, H., Owens, P., Zhang, G., McBratney, A., Hempel, J., Montanarella, L. and Schad, P.: 2010, Time for a Universal Soil Classification System. In: Gilkes, R.J. and Prakongkep, N. (Eds): Proceedings of the 19th World Congress of Soil Science, published on DVD, Symposium 1.4.1. Classification and information demand, IUSS, Brisbane, 48-51.

Hlavay, J., Jonas, K., Elek, S. and Inczedy, J.: 1978, Characterization of the particle size and the crystallinity of certain minerals by IR spectrophotometry and other instrumental methods II. Investigations on quartz and feldspar, Clays and Clay Minerals., 26, 139-143. DOI: 10.1346/CCMN.1978.0260209

Ivanova, E.N.: 1971, Soils of Central Yakutia, Pochvovedenie., No. 9, 3-17, (in Russian).

Jackson, M.L., Lim, C.H. and Zelazny, L.W.: 1986, Oxides, hydroxides, and aluminosilicates. In: Klute, A. (Ed.): Methods of soil analysis. Part 1. 2nd ed., Agronomy Monograph. No. 9.; SSSA: Madison, WI, 101-150.

Kimble, J.M. (Ed.).: 2004, Cryosols: Permafrost-affected Soils, Springer-Verlag, Berlin, XVIII, 726 pp.

Madejová, J. and Komadel, P.: 2001, Baseline studies of the clay minerals society source clays: Infrared methods, Clays and Clay Minerals., 49, 410-432. DOI: 10.1346/CCMN.2001.0490508

Madejová, J. and Komadel, P.: 2005, Information available from infrared spectra of the fine fraction of bentonites. In: Kloprogge, J.T. (Ed.): The application of vibrational spectroscopy of clay minerals and layered double hydroxides. CMS Workshop Lectures, 13. The Clay Mineral Society, Aurora, CO, 65-98.

Mavris, C., Egli, M., Plotze, M., Blum, J.D., Mirabella, A., Giaccai, D. and Haeberli, W.: 2010, Initial stages of weathering and soil formation in the Morteratsch proglacial area (Upper Engadine, Switzerland), Geoderma., 155, 359-371.

DOI: 10.1016/j.geoderma.2009.12.019

Mehra, O.P. and Jackson, M.L.: 1958, Iron oxide removal from soils and clays by a dithionite-citrate system 
buffered with sodium bicarbonate, Clays and Clay Minerals., 7, 317-327. DOI: 10.1346/CCMN

Pentrak, M., Madejová, J. and Komadel, P.: 2009. Acid and alkali treatment of kaolins, Clay Minerals., 44, 511523

DOI: 10.1180/claymin.2009.044.4.511

Reynolds, R.C.: 1980. Interstratified clay minerals. In: Brindley, G.W. and Brown, G. (Eds): Crystal Structure of Clay Minerals and their X-Ray Identification, Mineralogical Society, Monograph. No. 5.; London, 249-304.

Rieder, M., Cavazzini, G., D'yakonov, Yu., FrankKamenetskii, V., Gottardi, G., Guggenheim, S., Koval', P., Mueller, G., Neiva, A., Radoslovich, E., Robert, J-L., Sassi, F., Takeda, H., Weiss, Z., and Wones, D.: 1998, Nomenclature of the micas, Canadian Mineralogist., 36, 905-912.

Righi, D., Petit, S. and Bouchet, A.: 1993, Characterization of hydroxy-interlayered vermiculite and illite/smectite interstratified minerals from the weathering of chlorite in a Cryorthod., Clays and Clay Minerals., 41, 484495. DOI: 10.1346/CCMN.1993.0410409

Sanchez, P.A., Ahamed, S., Carre, F., Hartemink, A.E., Hempel, J., Huising, J., Lagacherie, P., McBratney, A.B., McKenzie, N.J., de Mendonca-Santos, M L., et al.: 2009, Digital Soil Map of the World, Science., 325, No. 5941, 680-681.

Simas, F.N.B., Schaefer, C.E.G.R., Melo, V.F., Guerra, M.B.B., Saunders, M., and Gilkes, R.J.: 2006, Claysized minerals in permafrost-affected soils (Cryosols) from King George Island, Antarctica, Clays and Clay Minerals., 54, 721-736. DOI: 10.1346/CCMN.2006.0540607

Sokolov, I. A.: 1991, Some Theoretical Results and Problems of Soil Studies in East Siberia and the Far East, Pochvovedenie., No. 5, 131-145, (in Russian).

Sugimoto, A., Yanagisawa, N., Naito, D., Fujita, N. and Maximov, T.C.: 2002, Importance of permafrost as a source of water for plants in East Siberian taiga, Ecological Research., 17, Issue 4, 493-503. DOI: $10.1046 / \mathrm{j} .1440-1703.2002 .00506 . \mathrm{x}$

Wilson, M.J.: 1999, The origin and formation of clay minerals in soils: past, present and future perspectives, Clay Minerals., 34, 7-25. DOI: $10.1180 / 000985599545957$

Wilson, M.J., Bain, D.C. and Duthie, D.M.L.: 1984. The soil clays of Great Britain. II Scotland, Clay Minerals., 19, 709-735.

DOI: 10.1180 /claymin.1984.019.5.03

World Reference Base for Soil Resources, 2006. 2nd edition World Soil Resources Reports 103. FAO, Rome. 